\title{
NOTES ON HERDMANIA MOMUS (SAVIGNY) FROM THE GULF OF THAILAND
}

\section{$\operatorname{AUTHOR}(S)$ :}

Senawong, Chokechai; Tokioka, Takasi

\section{CITATION:}

Senawong, Chokechai ... [et al]. NOTES ON HERDMANIA MOMUS (SAVIGNY) FROM THE GULF OF THAILAND. PUBLICATIONS OF THE SETO MARINE BIOLOGICAL LABORATORY 1971, 18(6): 407-411

ISSUE DATE:

1971-03-31

URL:

http://hdl.handle.net/2433/175651

RIGHT: 


\title{
NOTES ON HERDMANIA MOMUS (SAVIGNY) FROM THE GULF OF THAILAND ${ }^{1}$
}

\author{
Chokechai SENAWONG and TAKasi TOKIOKA \\ Seto Marine Biological Laboratory, Japan
}

With 1 Text-figure

Some solitary ascidians met with in the vicinity of Seto reminded the first author of a certain solitary ascidian which was seemingly common in some areas along the coast of the Gulf of Thailand. Then, he wished to identify that ascidian. Very fortunately, in response to his request Mr. Weerayudth Lauhajinda of the Biological Department, Faculty of Science and Arts, Kasetsart University, Bangkok sent him very kindly a material of that ascidian. It consists of nine specimens collected by one of Mr. LAUHAJINDA's students from the sand-muddy to muddy beach of the village of Ban Pe in Rayong Province on the southeastern coast of the Gulf of Thailand. The specimens were all found attached to rocks in the intertidal zone of the area.

Two of them were dissected by the second author and it was cleared immediately that they belonged to Herdmania momus (SAVIGNY) as recognized very easily by the existence of calcareous spicules unique to this species and also by the general internal morphology. At the same time, it was noted that fewer branchial plications and very complicatedly branched branchial tentacles of these specimens resemble closely those of Pyura (Halocynthia) pallida (Heller) f. formosae Michaelsen, 1908 that was described on many small (less than $20 \mathrm{~mm}$ ) specimens collected by Hans SANTER at Takao on the southwestern coast of Formosa (Michaelsen 1908). Then, the careful examination of the other 7 specimens was done by the first author and the check of the descriptions of specimens of the same species collected from the warm water region of the North West Pacific was made by the second author. And here, the separation of Michaelsen's formosae as a distinct form in Herdmania momus (SAvigny) is discussed and a possible biological significance of some morphology in the present specimens is suggested by both of them.

The authors want to express their hearty thanks to Mr. Launajinda for his kindness in offering them the specimens and giving information about the natural colouration, size, and habitat of the ascidian.

1) Contributions from the Seto Marine Biological Laboratory, No. 540.

Publ. Seto Mar. Biol. Lab., XVIII (6), 407-411, 1971. (Article 27) 


\section{Features noted in the specimens}

Roughly ovoid in shape. The external appearance of the specimens preserved in formalin is very similar to that described generally for Herdmania momus. They are rather smaller, in spite of their full ripe state of the gonad, only $20-25 \mathrm{~mm}$ long in the larger axis. The branchial and atrial siphons are rarely discernible on the body surface. The test is leathery, but soft; rather thick, 2-3 mm thick in general; somewhat translucent, in some specimens the outline of the alimentary canal and gonad

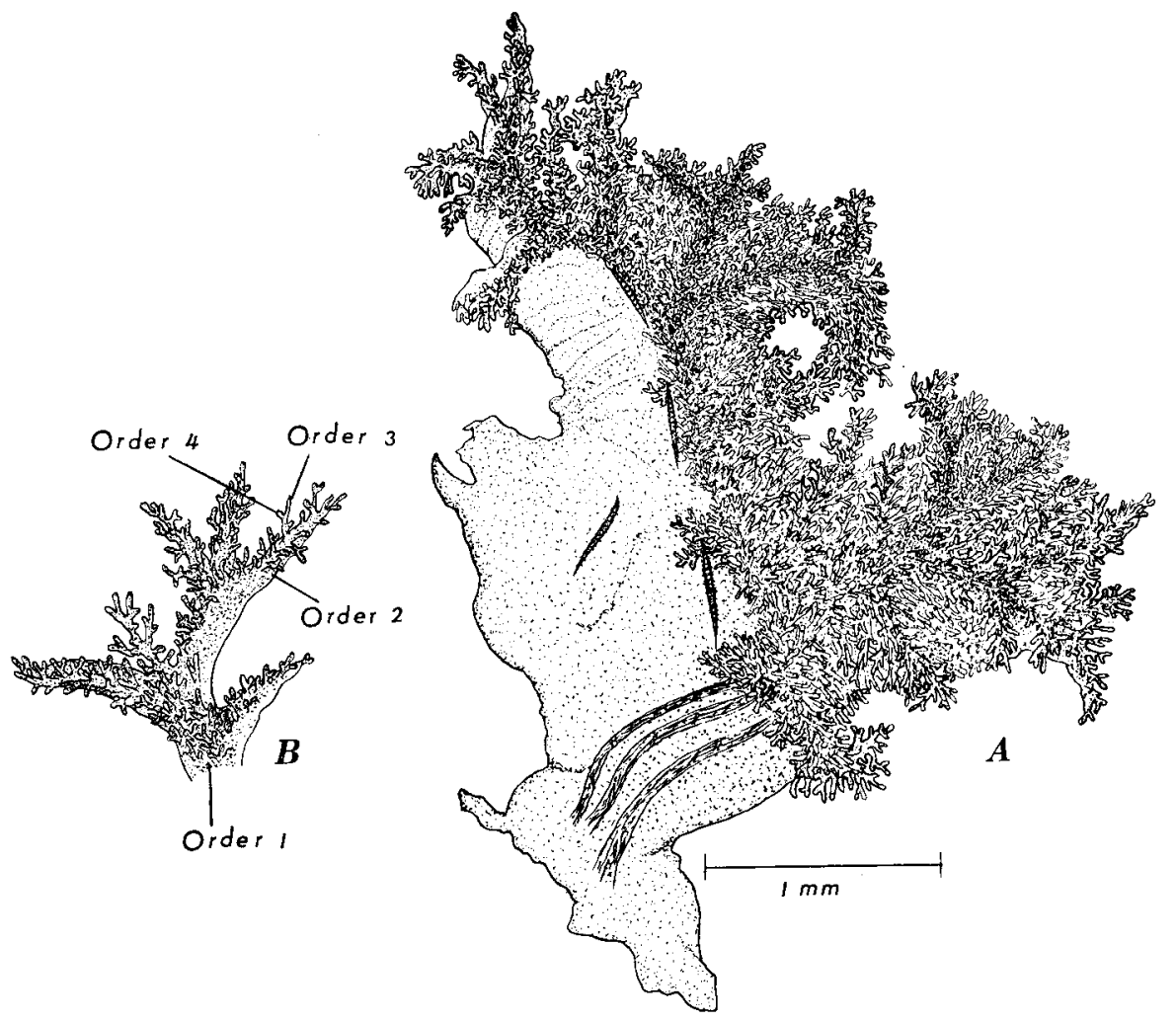

Fig. 1. Herdmania momus f. formosae (Michaelsen). A: One of larger tentacles, B: A branch from the same tentacle, branching orders are shown.

can be seen through the test vaguely; and coloured when alive as in the present preservative, lightly brownish. The inner layer of the test is gelatinous.

No peculiarities are found in the internal morphology, but in the branching order of branchial tentacles and the number of branchial plications. The tentacles are about 20 including larger and smaller ones, but excluding minute ones; the arrangement is usually rather irregular, though very probably the fundamental arrangement is large-minute-small-minute-large. In larger tentacles, there are found 
small branches of the fourth order, though not so abundantly, thus the tentacles may attain a big size of an extremely complicated configuration and form together a kind of complete sieve at the entrance to the branchial sac.

There are generally seven plications on each side of the branchial sac, in some specimens a rudimentary eighth fold may be added on the right side along the endostyle; the rudimentary fold is usually represented by two to three inner longitudinal vessels gathered and is much less prominent in the posterior half of the sac. The arrangement of inner longitudinal vessels is as follows.

$2 \mathrm{l}$ and $23 \mathrm{~mm}$ long specimens:

$$
\begin{array}{lll}
\text { Left } & \mathrm{D} & 1(10) 1(13-14) 1-2(13-14) 2(11-12) 1-3(11) 1-3(10) \\
& 1(5-7) 1 \mathrm{~V} . \\
\text { Right } \quad \mathrm{D} & 0-1(9) 1-2(12-13) 1-3(13-14) 1-3(11-14) 1-3(12-13) \\
& 2(10) 1(6-7) 0-1 \mathrm{~V}
\end{array}
$$

Two $24 \mathrm{~mm}$ long specimens:

$$
\begin{array}{lll}
\text { Left } & \mathrm{D} & 1(10-12) 1-2(12-15) 1-3(13-15) 1-3(13-15) 2-3(11-14) \\
& 2(10) 1-2(7) 1 \mathrm{~V} \\
\text { Right } \quad \mathrm{D} & 1-2(8-10) 1-2(12-13) 1-2(14) 1-2(14-15) 1-2(12-14) \\
& 1(11-13) 1(7-9) 0-1(2-3) 0 \mathrm{~V}
\end{array}
$$

Transverse vessels are arranged as thick-thin-medium-thin-thick, parastigmatic vessels are present, though not regularly; 7-10 elongate stigmata in a mesh in the middle portion of the sac. The ciliated groove is G-shaped, open anteriorly and with horns incurled.

\section{Discussions}

Mighaelsen (1908) defined the form formosae by comparing it with f. papietensis (Herdman) and f. ceylonica (Herdman) (p. 267). The most characteristic features of f. formosae are seven branchial plications on each side of the sac and complicatedly branched branchial tentacles. The seventh (ventral-most) folds are much narrower than others and become less remarkable posteriorly on both sides, and larger tentacles show clearly the sign of branching of the fourth order (p. 268). Forma papietensis has seven well developed folds on each side of the branchial sac, and in $f$. ceylonica that is provided with 7 branchial plications on each side, only the seventh (ventral-most) fold on the left side is narrower than others. In spite of such differences, these three formae may be said to be very similar to one another in respect to the number of branchial plications. The branchial tentacles are, however, much simpler in f. papietensis and f. ceylonica than in f. formosae; even larger tentacles in the former are furnished only rarely with branches of the second order (p. 268).

The present specimens from the Gulf of Thailand conform exactly to f. formosae in the branching order of tentacles and evidently are related very closely with the same form in the number of branchial plications. The existence of an excess rudi- 
mentary fold on the right side in some of the present specimens does not seem to be a very significant difference. The specimens may be safely concluded to be identical with $\mathrm{f}$. formosae, if the latter is accepted as a form of some taxonomical significance.

VAN NAME (1954) recognized none of the forms which had been recognized by Michaelsen (1919) as of some taxonomical significance, but the best marked Australian var. grandis (HELLER), stating "—but these are certainly mostly not geographical races or true subspecies, as their wide occurrence and irregular overlapping distribution show" (p. 344), and regarded West Indian specimens, having usually eight or nine branchial folds on a side and with tentacles which are at the maximum two or three times compound (their branches are not very numerous) and bear broad membranes (p. 343), as typical Herdmania momus.

If the features characteristic to respective formae are closely correlated with, for instance, the remarkable difference in body size probably attributable to the rapid or retarded growth respectively in the waters of higher or lower (at higher latitudes or at deeper levels) temperature, or similarly with the fast or slow maturation, then such formae may be regarded as geographical or ecological forms but not as races of some taxonomical significance steadily maintaining their unique, even minor, features by heredity.

Generally, the number of branchial plications and the order of branching of branchial tentacles are under similar conditions increased with the body size. To see whether or not the characteristic features of $\mathrm{f}$. formosae are correlated with its smaller body size, the same features are compared with those of specimens of other formae, collected in or near the North West Pacific and of similar body size. VAN Name (1918) examined many specimens of Pyura pallida from Philippine waters and identified them with the typical form of the species, known at that time from Tahiti, Palao, Ceylon, the western Indian Ocean, Cape of Good Hope, and the West Indies, because they were provided with 8-9 branchial folds on the left and 9 on the right side (p. 79); var. billitonensis SLuiter, 1885 from Billiton was treated by him as a synonym of the type form (p. 76). The Japanese specimens from the shallow waters are reddish when alive and usually provided with 9-10 folds on a side (TokiokA 1953, pp. 279-280), even a $10 \mathrm{~mm}$ long specimen collected near the Seto Marine Biological Laboratory bears 8 folds on each side (TокіокA 1949, p. 44). A $22 \mathrm{~mm}$ long specimen from Kagosima in southern Kyosyu Island has 8 folds on a side, though the eighth is not so prominent as others (Tokioka 1967, p. 206). A $18 \mathrm{~mm}$ long specimen from Saipan Island of the Mariana Islands is provided with 8 and 1 rudimentary folds on the left and 9 folds on the right side (Tокіока 1967, p. 206). Even a $11 \mathrm{~mm}$ long specimen from Palao Island of the West Caroline Islands has 8 folds on each side (Tокıок 1950, p. 150). A $25 \mathrm{~mm}$ long individual from the Arafura Sea is furnished with 9 folds on each side (Tokıora 1952, p. 139), and in 5 to $49 \mathrm{~mm}$ long specimens from Noumea, New Caledonia there are 8, 8 and 1 rudimentary, or 9 folds on a side (Tokıoka 1961, p. 132). The existence of seven plications on a side 
seem to be limited to the specimens occurring on or near the continental coast in the tropical region of the North West Pacific.

The complicated state of branchial tentacles in the present specimens reminds the authors of the specimens of Microcosmus exasperatus Heller collected near Amoy, in which the branchial tentacles are ramified much more complicatedly than in specimens from other localities (Tokioka 1967, pp. 213-215). If such a complicated ramification of tentacles could be recognized as really of an adaptive effect to prevent the inflow of silt or detritus, which might be abundant at localities in the neritic waters along the continent, this feature together with fewer branchial plications will be enough to qualify $\mathrm{f}$. formosae to be a race, or at least a very distinct and well separated genotype, of some taxonomical significance. The present authors tend now towards the recognition of this form.

\section{REFERENCES}

Michaelsen, W. (1908): Die Pyuriden (Halocynthiiden) des Naturhistorischen Museums zu Hamburg. Mitteil. aus d. Naturhist. Mus., vol. 25, pp. 227-285, 2 pls.

Tokioka, T. (1949): Contributions to Japanese ascidian fauna II. Notes on some ascidians collected chiefly along the coast of Kii Peninsula. Publ. Seto Mar. Biol. Lab., vol. 1, no. 2, pp. 39-64, 16 figs., PI. 8.

_-_ (1950): Ascidians from the Palao Islands. I. Publ. Seto Mar. Biol. Lab., vol. 1, no. 3, pp. 115-150, 23 figs., Pls. 9-10.

- (1952): Ascidians collected by Messrs. Renzi WADA and Seizi WADA from the pearl-oyster bed in the Arafura Sea in 1940. Publ. Seto Mar. Biol. Lab., vol. 2, no. 2, pp. 91-142, 29 figs.

(1953): Ascidians of Sagami Bay. Iwanami Shoten, Tokyo.

- (1961): Ascidians collected during the Melanesia Expedition of the O $_{\text {saka Museum of Natural }}$ History. I. Ascidians presented by Dr. R.L.A. Catala of the Aquarium of Noumea. Publ. Seto Mar. Biol. Lab., vol. 9, no. 1, pp. 103-138, I5 figs., Pl. 5.

-_ (1967): Pacific Tunicata of the United States National Museum. U.S. Nat. Mus. Bull. 251, 247 pp., 105 pp.

Van Name, W.G. (1918): Ascidians from the Philippines and adjacent waters. U.S. Nat. Mus. Bull. 100, vol. 1, part 2, pp. 49-174, 115 figs., Pls. 23-33.

- (1945): The North and South American ascidians. Bull. American Mus. Nat. Hist., vol. 84, 476 pp., 327 figs., 31 pls. 